Forestry and Grassland Received on: 12/07/2021 Accepted on: 16/01/2022

\title{
Silage Quality of two energy-cane cultivars produced with different additives
}

Qualidade da silagem de duas cultivares de cana-energia produzidas com diferentes aditivos

SILVA, Vanderli Luciano da ${ }^{1}$ https://orcid.org/0000-0002-8449-4639

FREITAS, Paulo Vitor Divino Xavier de ${ }^{2}$ https://orcid.org/0000-0003-2671-1030

FRANÇA, Aldi Fernandes de Souza ${ }^{1}$ https://orcid.org/0000-0001-6715-0618

FERREIRA, Reginaldo Nassar ${ }^{3}$ https://orcid.org/0000-0002-0545-1439
OLIVEIRA, Leonardo Guimarães de ${ }^{1}$ https://orcid.org/0000-0003-0508-0655

LEANDRO, Wilson Mozena ${ }^{4}$ https://orcid.org/0000-0002-7513-5976

REBOUÇAS, Geovanne Ferreira ${ }^{1}$, https://orcid.org/0000-0002-4411-7564

SILVA NETO, Carlos de Melo e https://orcid.org/0000-0001-8624-3836

${ }^{1}$ Animal Science Department, Federal University of Goias, Goias, Brazil

${ }^{2}$ Animal Science Department, Federal University of Goias; State University of Goias, Goias, Brazil

${ }^{3}$ Biology Institute II, Federal University of Goias, Goias, Brazil

${ }^{4}$ Agronomy Department, Federal University of Goias, Goias, Brazil

${ }^{5}$ Federal institute of Goiás, Brazil

*Mail for correspondence: paulovitor_freitas@ hotmail.com

\section{ABSTRACT}

This study examined the quality of silage from two cultivars of energy cane (Saccharum spontaneum) produced with different additives. The experiment was laid out in a completely randomized design with a $2 \times 5$ factorial arrangement of treatments consisting of two cultivars (VG3, VG1126) and four additives (1\% urea; $1 \% \mathrm{NaOH} ; 1 \% \mathrm{CaO}$; and $1.0 \times 1011 \mathrm{CFU} \mathrm{g}^{-1}$ of Lactobacillus plantarum- LP) + control, with eight replicates. Experimental mini-silos were used, which were opened 72 days after ensiling. The dry matter $(\mathrm{DM})$, crude protein $(\mathrm{CP})$, organic matter $(\mathrm{OM})$, mineral matter $(\mathrm{MM})$, ether extract (EE), neutral detergent fiber (NDF) and acid detergent fiber (ADF) contents, and silage degradability were. We identified significant interactions effect between cultivar and type of additive for DM, CP, EE, NDF. ADF. Organic and mineral matter percentage were similar between the two cultivars. LP was the least beneficial additive for DM degradation. After $72 \mathrm{~h}$ of fermentation, in vitro NDF degradation of cultivar VG3 increased due to urea, $\mathrm{NaOH}$, and $\mathrm{CaO}$, whereas degradation cultivar VG1126 decreased when inoculated with $\mathrm{LP}$ or $\mathrm{CaO}$. The $\mathrm{NaOH}$ and $\mathrm{CaO}$ improved silage degradability thus improving its quality. The use of LP in the present study did not benefit silage for energycane cultivars. The use of $\mathrm{NaOH}$ and $\mathrm{CaO}$ improves the quality of the silage, two varieties 
of sugarcane energy VG3 and VG1126, enabling its use with better efficiency for animal feed.

Keywords: chemical and microbial inoculum, chemical composition, forage preservation, in vitro degradability

\section{RESUMO}

Este estudo avaliou a qualidade da silagem de duas cultivares de cana-de-energia (Saccharum spontaneum) produzidas com diferentes aditivos. O experimento foi instalado em delineamento inteiramente casualizado, com arranjo fatorial $2 \times 5$ de tratamentos composto por duas cultivares (VG3, VG1126) e quatro aditivos (1\% uréia; $1 \% \mathrm{NaOH} ; 1 \% \mathrm{CaO}$; e 1,0 $\times 1011$ UFC g -1 de Lactobacillus plantarum- LP) + controle, com oito repetições. Foram utilizados minisilos experimentais, os quais foram abertos 72 dias após a ensilagem. Os teores de matéria seca (MS), proteína bruta (PB), matéria orgânica (MO), matéria mineral (MM), extrato etéreo (EE), fibra em detergente neutro (FDN) e fibra em detergente ácido (FDA) e degradabilidade da silagem foram avaliados. Identificou-se efeito de interação significativo entre cultivar e tipo de aditivo para MS, PB, EE, FDN. ADF. As porcentagens de matéria orgânica e mineral foram semelhantes entre as duas cultivares. LP foi o aditivo menos benéfico para a degradação da MS. Após 72 h de fermentação, a degradação in vitro da FDN da cultivar VG3 aumentou devido à uréia, $\mathrm{NaOH}$ e $\mathrm{CaO}$, enquanto a degradação da cultivar VG1126 diminuiu quando inoculada com $\mathrm{LP}$ ou $\mathrm{CaO}$. O NaOH e o $\mathrm{CaO}$ melhoraram a degradabilidade da silagem, melhorando assim sua qualidade. $\mathrm{O}$ uso da LP no presente estudo não beneficiou a silagem para cultivares de cana-de-energia. $\mathrm{O}$ uso de $\mathrm{NaOH}$ e $\mathrm{CaO}$ melhora a qualidade da silagem, duas variedades de energia da cana-de-açúcar VG3 e VG1126, possibilitando seu uso com melhor eficiência para ração animal

Palavras-chave: inoculo químico e microbiano, composição química, preservação de forragem, degradabilidade in vitro.

\section{INTRODUCTION}

In view of the demand for food and the need to intensify agricultural systems, several lines of research focus on the production scenario. One of these highly researched fields is the breeding of sugarcane, given its importance as the main raw material in the production of ethanol and sugar as well as its wide use as a forage for animal feed. In addition to being highly productive, the crop has its greatest nutritional value in periods of water scarcity - a time when the production of other forage plants is stagnant (Moraes et al., 2017).
One of the major obstacles to using sugar cane on farms is the cost of labor for harvesting and transport. However, the material can be chopped, processed and stored in the form of silage, substantialy reducing production costs (Moraes et al., 2017; Rigueira et al., 2018).

It is important to note that the use of inoculants is essential to obtain highquality sugar cane silage. When inoculants are not used, there are increases in the generation of ethanol, effluents, and gases, which translate into loss of nutritional value of the silage (Dias et al., 2014).

Various materials are available for the different sectors (ethanol, sugar and 
animal feed production), but energy cane (Saccharum spontaneum) has attracted the attention of producers (Matsuoka et al., 2014; Guimarães et al., 2016). Originating from the cross of ancestors and commercial hybrids, energy cane can be grown in marginal areas, poorer soils and in regions with unstable climate. When grown in low-fertility soils and in unfavorable environmental conditions, energy cane can produce more than twice as much as conventional cane in the same conditions (Matsuoka et al., 2014; Antonini et al., 2017).

Another important characteristic of energy cane is high fiber production. This, however, does not reduce the possibilities of using it in ruminant diets. Owing to its high biomass yield, energy cane has the potential to produce a considerably larger amount of cellulosic sugars per hectare than sugar cane.

Given its many desirable characteristics, energy cane is a promising agricultural plant. Nonetheless, research is warranted to determine its real potential for use in animal feed. Therefore, the present study was developed to examine the chemical composition and degradability of silage from two cultivars of energy cane treated with different additives.

\section{MATERIALS AND METHODS}

The study was conducted from 10 Oct, 2016, to 15 Nov 15, 2018, at Campus II of the Federal University of Goiás, located in Goiânia-GO, Brazil (16 $35^{\prime} 52^{\prime}, \mathrm{S}, 49^{\circ} 17^{\prime} 11^{\prime} \mathrm{W}, 723 \mathrm{~m}$ above sea level).The climate of the region is classified as semi-humid tropical (Aw), with a well defined dry season from May to October. Average annual temperature is $23.2{ }^{\circ} \mathrm{C}$, with minimum and maximum means of 17.9 and $28.9{ }^{\circ} \mathrm{C}$, respectively, and annual precipitation is $1578 \mathrm{~mm}$ (Pereira et al., 2010). Average air humidity in the region is $71 \%$, with the lowest indices occurring in the month of August.

The experiment was laid out in a completely randomized design with a $2 \times 5$ factorial arrangement consisting of two cultivars and four additives + control, with eight replicates, totaling 80 experimental units.

Two energy cane (Saccharum spontaneum) cultivars, VG3 and VG1126, were used in the following treatments: Control - production of energy-cane silage without the use of additives; and the following four additves: LP: - Lactobacillus plantarum (SILOBAC 5 strains CH6072 and L286, with $1.0 \times 1011 \mathrm{CFU} \mathrm{g}^{-1}$ ) used at the rate of $50 \mathrm{~g}$ for $50 \mathrm{Mg}$ of fresh cane, following the manufacturer's recommendations; Urea - $\left(\mathrm{NH}_{2}\right)_{2} \mathrm{CO}$, at $1 \%$ of the fresh mass; $\mathbf{N a O H}$ - sodium hydroxide, at $1 \%$ of the fresh mass (using caustic soda at a concentration of 9699\%); and CaO - calcium oxide, using virgin lime as a source, at $1 \%$ of the fresh mass. All additives were diluted in water at the rate of $5 \mathrm{~L}$ of water for $100 \mathrm{~kg}$ of fresh cane. The control received $5 \mathrm{~L}$ of water (without any additives) for each $100 \mathrm{~kg}$ of fresh cane to balance the moisture content with those of the other treatments.

The second-ratoon crop cycle of energy cane was harvested manually at $0.05 \mathrm{~m}$ above soil level. The forage (whole plant) was ground into $10-20 \mathrm{~mm}$ particles through a stationary chopper. Before ensiling, samples of each cultivar were dried in a forced-air oven at $55^{\circ} \mathrm{C}$, for $72 \mathrm{~h}$, to determine the partial dry matter (DM). Subsequently, the samples were ground through a Willey mill with a 1-mm mesh sieve and their composition was determined in 
accordance with the methodology of Detmann et al. (2012).

After the material was chopped, the additives were applied and homogenized in the proportions mentioned above. Next, the material was added to plastic buckets that were used as mini-silos (29 $\mathrm{cm}$ wide $\times 31 \mathrm{~cm} \mathrm{high),} \mathrm{where} \mathrm{the} \mathrm{mass}$ was compacted using iron rods until reaching a density of $500-650 \mathrm{~kg}$ of silage $\mathrm{m}^{-3}$. Before ensiling, the buckets were weighed. Fine sand $(1 \mathrm{~kg})$, cotton fabric and a shade cloth were added to the bottom of each container to retain effluents for later quantification.

After 72 days of anaerobic fermentation, the mini-silos were weighed and opened. For analysis, samples were collected from the central part of the mini-silos.

To determine the partial DM, the subsamples were dried in a forced-air oven at $55^{\circ} \mathrm{C}$ until reaching constant weight. Subsequently, they were ground through a Willey mill with a 1-mm sieve for later determination of the percentages of DM, crude protein $(\mathrm{CP})$, mineral matter $(\mathrm{MM})$, organic matter $(\mathrm{OM})$, ether extract (EE), neutral detergent fiber (NDF) and acid detergent fiber (ADF), as proposed by Detmann et al. (2012).

The methodology described by Ankom technology (2012) was applied to measure the in vitro DM degradability of the silage. The rumen fluid used for this procedure was collected manually from different regions in the rumen of two
Nellore animals that were fed a diet based on pasture (Brachiaria grass) and mineral salt in equal volumes. The fluid was stored in a thermal container until arriving at the laboratory, where it was placed in a blender at high high speed for $10 \mathrm{~s}$, purged with $\mathrm{CO}_{2}$, and then filtered through two layers of cotton fabric. The in vitro NDF degradability was determined according to Detmann et al. (2012). The experiment protocol was approved by the Ethics Committee on the use of animals at the Federal University of Goiás by opinion $N^{\circ}$. 044/12.

The Shapiro-Wilk and Bartlett tests were applied $(\alpha=0.05)$ to check responsevariable data for normality and homoscedasticity assumptions. The response variables that met the assumptions were subjected to ANOVA and means were compared by the ScottKnott test at the $5 \%$ probability level.

To compare all the variables involved in the experiment and understand the multivariate relationships between cultivars and treatments (two cultivars $x$ four additives + control), principal component analysis was performed using a correlation matrix.

\section{RESULTS}

Despite having a lower percentage of cellulose, cultivar VG3, showed a higher lignin percentage than cultivar VG1126.

Table 1. Lignocellulosic composition of energy-cane cultivars VG3 and VG1126 (\% of neutral detergent fiber).

\begin{tabular}{lll}
\hline Parameter & VG3 & VG1126 \\
\hline Cellulose & 6.28 & 28.58 \\
Hemicellulose & 17.80 & 21.51 \\
Lignin & 48.15 & 23.65 \\
\hline
\end{tabular}

The similar chemical composition of the cultivars prior to ensiling is remarkable, 
with DM and NDF being the most discrepant components in content (Table 2).

Table 2. Mean chemical composition values determined in the fresh mass of energy cane cultivars before ensiling.

\begin{tabular}{llllllll}
\hline Cultivar & \multicolumn{9}{l}{ Parameter } & & & & & \\
\cline { 2 - 7 } & DM & CP & OM & EE & MM & NDF & ADF \\
\hline VG3 & 33.93 & 2.09 & 98.32 & 2.28 & 1.67 & 52.74 & 29.20 \\
VG1126 & 44.65 & 2.18 & 98.30 & 2.55 & 1.69 & 63.23 & 36.08 \\
\hline
\end{tabular}

DM - dry matter; CP - crude protein; OM - organic matter; EE - ether extract; MM - mineral matter; NDF - neutral detergent fiber; ADF - acid detergent fiber.

Chemical composition analysis of silage from the energy-cane cultivars treated with different additives (Table 3) revealed that there was a cultivar $\mathrm{x}$ additive interaction for the percentages of DM, CP, EE, NDF and ADF.

The VG3 silages that best maintained their DM levels during fermentation were those where no additive was used or where $\mathrm{CaO}$ was added. In the silage from cultivar VG1126, on the other hand, non-use of inocula significantly reduced the DM content (Table 3 ).

When the factors were analyzed separately (Table 3), inoculation with urea increased the $\mathrm{CP}$ levels of the silages from both cultivars, with greater evidence seen in cultivar VG3. Inoculation of cultivar VG3 with LP resulted in decreased $\mathrm{EE}$ contents, whereas in the silage from cultivar
VG1126 this reduction occurred with the use of $\mathrm{NaOH}$.

Between the two cultivars, when not inoculated or when treated with $\mathrm{NaOH}$ or $\mathrm{CaO}$, cultivar VG3 had its NDF content reduced. Comparing only the inocula, urea, $\mathrm{NaOH}$ and $\mathrm{CaO}$ were found to reduce the NDF contents of cultivar VG1126, whereas in cultivar VG3, NDF decreased with the use of $\mathrm{CaO}$.

With the exception of cultivar VG1126 inoculated with LP, the ADF levels were similar between the cultivars. In the comparison between inocula, the lowest ADF levels in cultivar VG3 were observed when it was inoculated with urea and $\mathrm{NaOH}$, whereas for cultivar VG1126 this occurred when it was inoculated with urea, $\mathrm{NaOH}$ and also with $\mathrm{CaO}$.

Table 3. Mean percentage values of chemical components determined in energy-cane silages (VG3 and VG1126) subjected to different treatments.

\begin{tabular}{|c|c|c|c|c|c|c|c|c|}
\hline \multirow[b]{2}{*}{ Variable } & \multirow[b]{2}{*}{ Additive } & \multicolumn{2}{|l|}{ Cultivar } & \multirow[b]{2}{*}{ Mean } & \multirow[b]{2}{*}{$\mathbf{P}_{1}$} & \multirow[b]{2}{*}{$\mathbf{P}_{2}$} & \multirow[b]{2}{*}{$\mathbf{P}_{3}$} & \multirow[b]{2}{*}{ CV\% } \\
\hline & & VG3 & VG1126 & & & & & \\
\hline \multirow{7}{*}{ DM } & Control & $32.33 \mathrm{bA}$ & $33.12 \mathrm{aC}$ & $32.73 \mathrm{D}$ & \multirow{6}{*}{$<0.001$} & \multirow{6}{*}{$<0.001$} & \multirow{6}{*}{$<0.001$} & \multirow{6}{*}{4.06} \\
\hline & LP & $31.42 \mathrm{bB}$ & $40.54 \mathrm{aA}$ & 35.98B & & & & \\
\hline & Urea & $31.22 \mathrm{bB}$ & $39.97 \mathrm{aA}$ & $35.60 \mathrm{~B}$ & & & & \\
\hline & $\mathrm{NaOH}$ & $30.10 \mathrm{bC}$ & $37.84 \mathrm{aB}$ & $33.98 \mathrm{C}$ & & & & \\
\hline & $\mathrm{CaO}$ & $35.01 \mathrm{bA}$ & $40.33 \mathrm{aA}$ & $37.67 \mathrm{a}$ & & & & \\
\hline & Mean & $32.01 \mathrm{~b}$ & $38.38 \mathrm{a}$ & & & & & \\
\hline & Control & $1.98 \mathrm{aB}$ & $2.98 \mathrm{aB}$ & $2.48 \mathrm{~B}$ & & & & \\
\hline
\end{tabular}




\begin{tabular}{|c|c|c|c|c|c|c|c|c|}
\hline \multirow{5}{*}{$\mathrm{CP}$} & LP & $1.63 \mathrm{aB}$ & $2.52 \mathrm{aB}$ & $2.07 \mathrm{~B}$ & \multirow{5}{*}{0.685} & \multirow{5}{*}{$<0.001$} & \multirow{5}{*}{$<0.001$} & \multirow{5}{*}{28.81} \\
\hline & Urea & $10.88 \mathrm{aA}$ & $7.72 \mathrm{bA}$ & $9.30 \mathrm{a}$ & & & & \\
\hline & $\mathrm{NaOH}$ & $1.91 \mathrm{aB}$ & $2.84 \mathrm{aB}$ & $2.37 \mathrm{~B}$ & & & & \\
\hline & $\mathrm{CaO}$ & $1.74 \mathrm{aB}$ & $2.57 \mathrm{aB}$ & $2.15 \mathrm{~B}$ & & & & \\
\hline & Mean & $3.63 \mathrm{a}$ & $3.72 \mathrm{a}$ & & & & & \\
\hline \multirow{6}{*}{ OM } & Control & $98.26 \mathrm{aA}$ & $97.97 \mathrm{aA}$ & $98.12 \mathrm{a}$ & \multirow{6}{*}{0.400} & \multirow{6}{*}{$<0.001$} & \multirow{6}{*}{0.980} & \multirow{6}{*}{0.75} \\
\hline & LP & $97.25 \mathrm{aB}$ & $97.08 \mathrm{aB}$ & $97.17 \mathrm{~B}$ & & & & \\
\hline & Urea & $97.41 \mathrm{aB}$ & $97.26 \mathrm{aB}$ & $97.33 \mathrm{~B}$ & & & & \\
\hline & $\mathrm{NaOH}$ & $95.90 \mathrm{aC}$ & $95.93 \mathrm{aC}$ & $95.92 \mathrm{C}$ & & & & \\
\hline & $\mathrm{CaO}$ & $96.20 \mathrm{aC}$ & $96.10 \mathrm{aC}$ & $96.15 \mathrm{C}$ & & & & \\
\hline & Mean & $97.01 \mathrm{a}$ & $96.87 \mathrm{a}$ & & & & & \\
\hline \multirow{6}{*}{$\mathrm{EE}$} & Control & $2.46 \mathrm{aA}$ & $1.95 \mathrm{bC}$ & $2.20 \mathrm{~B}$ & \multirow{6}{*}{0.005} & \multirow{6}{*}{$<0.001$} & \multirow{6}{*}{0.001} & \multirow{6}{*}{22.62} \\
\hline & LP & $1.25 \mathrm{bB}$ & $1.80 \mathrm{aC}$ & $1.53 \mathrm{C}$ & & & & \\
\hline & Urea & $2.06 \mathrm{aA}$ & $2.10 \mathrm{aC}$ & $2.08 \mathrm{~B}$ & & & & \\
\hline & $\mathrm{NaOH}$ & $2.17 \mathrm{bA}$ & $2.97 \mathrm{aA}$ & $2.57 \mathrm{a}$ & & & & \\
\hline & $\mathrm{CaO}$ & $1.81 \mathrm{bA}$ & $2.45 \mathrm{aB}$ & $2.13 \mathrm{~B}$ & & & & \\
\hline & Mean & $1.95 \mathrm{~b}$ & $2.25 \mathrm{a}$ & & & & & \\
\hline \multirow{6}{*}{ MM } & Control & $1.70 \mathrm{aC}$ & $2.07 \mathrm{aB}$ & $1.89 \mathrm{C}$ & \multirow{6}{*}{0.283} & \multirow{6}{*}{$<0.001$} & \multirow{6}{*}{0.905} & \multirow{6}{*}{23.44} \\
\hline & LP & $2.74 \mathrm{aB}$ & $2.78 \mathrm{aB}$ & $2.76 \mathrm{~B}$ & & & & \\
\hline & Urea & $2.58 \mathrm{aB}$ & $2.73 \mathrm{aB}$ & $2.66 \mathrm{~B}$ & & & & \\
\hline & $\mathrm{NaOH}$ & $4.09 \mathrm{aA}$ & $4.05 \mathrm{aA}$ & $4.07 \mathrm{a}$ & & & & \\
\hline & $\mathrm{CaO}$ & $3.79 \mathrm{aA}$ & $4.13 \mathrm{aA}$ & $3.96 \mathrm{a}$ & & & & \\
\hline & Mean & $2.98 \mathrm{a}$ & $3.15 \mathrm{a}$ & & & & & \\
\hline \multirow{6}{*}{ NDF } & Control & $64.78 \mathrm{bB}$ & $69.61 \mathrm{aA}$ & $67.20 \mathrm{~B}$ & \multirow{6}{*}{$<0.001$} & \multirow{6}{*}{$<0.001$} & \multirow{6}{*}{$<0.001$} & \multirow{6}{*}{3.59} \\
\hline & LP & 71.67aA & $69.71 \mathrm{aA}$ & $70.69 a$ & & & & \\
\hline & Urea & $65.10 \mathrm{aB}$ & $65.21 \mathrm{aB}$ & $65.15 \mathrm{C}$ & & & & \\
\hline & $\mathrm{NaOH}$ & $59.35 \mathrm{bC}$ & $63.55 \mathrm{aB}$ & $61.45 \mathrm{D}$ & & & & \\
\hline & $\mathrm{CaO}$ & $52.12 \mathrm{bD}$ & $63.80 \mathrm{aB}$ & $57.96 \mathrm{E}$ & & & & \\
\hline & Mean & $62.60 \mathrm{~b}$ & $66.38 \mathrm{a}$ & & & & & \\
\hline \multirow{6}{*}{$\mathrm{ADF}$} & Control & $37.16 \mathrm{aB}$ & $39.19 \mathrm{aA}$ & $38.18 \mathrm{a}$ & \multirow{6}{*}{0.175} & & & \\
\hline & LP & $41.40 \mathrm{aA}$ & $38.01 \mathrm{bA}$ & $39.70 \mathrm{a}$ & & & & \\
\hline & Urea & $35.50 \mathrm{aC}$ & $35.68 \mathrm{aB}$ & 35.59B & & $<0.001$ & 0.002 & 7.65 \\
\hline & $\mathrm{NaOH}$ & $33.74 \mathrm{aC}$ & $34.58 \mathrm{aB}$ & $34.16 \mathrm{~B}$ & & & & \\
\hline & $\mathrm{CaO}$ & $29.75 \mathrm{bD}$ & $34.30 \mathrm{aB}$ & $32.03 \mathrm{C}$ & & & & \\
\hline & Mean & $35.51 \mathrm{a}$ & $36.35 \mathrm{a}$ & & & & & \\
\hline
\end{tabular}

Means followed by common lowercase letters in the row and uppercase letters in the column do not differ from each other according to the Scott Knott test at the 5\% probability level.

$\mathrm{DM}$ - dry matter; $\mathrm{CP}$ - crude protein; $\mathrm{OM}$

- organic matter; EE - ether extract; MM

- mineral matter; NDF - neutral detergent fiber; $\mathrm{ADF}$ - acid detergent fiber.

Inocula: Control - no inoculum; LP Lactobacillus plantarum; Urea - urea; $\mathrm{NaOH}$ - sodium hydroxide; $\mathrm{CaO}$ calcium oxide. $\mathrm{P}_{1}$ - difference between cultivars; $\mathrm{P}_{2}$ - difference between additives; $\mathrm{P}_{3}-$ cultivar $\times$ additive interaction.

Similar OM contents were found in the two energy-cane cultivars (Table 3). Organic matter was influenced by the use of additives in the ensiling process, with 
highest values found in the silage that received no additives, followed by the silages treated with LP and urea. The lowest values for this variable were seen in the silages that received $\mathrm{NaOH}$ and $\mathrm{CaO}$, whose results were similar.

Mineral matter contents responded similarly in the two cultivars, being influenced only by the type of additive used. The results found for MM are opposite to those obtained for OM. The highest MM levels were observed in the silages treated with $\mathrm{NaOH}$ and $\mathrm{CaO}$, followed by those that received LP and urea. The MM levels in the silage that did not receive any type of inoculum was lower than in the others, for both cultivars (Table 3 ).

Below are the mean in vitro DM degradability values of the silages from the two energy-cane cultivars (Table 4). The soluble fraction (SF) of the silage from cultivar VG3 was lower than that of cultivar VG1126, only when the former was not inoculated. As for the inocula used, $\mathrm{CaO}$ stood out, increasing the SF of cultivar VG3. In cultivar VG1126, however, the SF content decreased regardless of the inoculum used.

With the exception of the silages inoculated with LP, degradation was higher in cultivar VG3 than in VG1126 at both fermentation times evaluated (48 $h$ and $72 \mathrm{~h}$ ). When the inocula were evaluated for their efficiency, the greatest degradation in cultivar VG3 was achieved with the use of $\mathrm{CaO}$. In VG1126, the best degradation was obtained with the use of $\mathrm{NaOH}$.

Table 4 Table 4 . Mean in vitro dry matter degradability values (\%) in silages from two energy-cane cultivars treated with different additives, at 48 and $72 \mathrm{~h}$.

\begin{tabular}{|c|c|c|c|c|c|c|c|c|}
\hline \multirow{2}{*}{ Variable } & \multirow[b]{2}{*}{ Additive } & \multicolumn{2}{|l|}{ Cultivar } & \multirow{2}{*}{ Mean } & \multirow{2}{*}{$\mathrm{P}_{1}$} & \multirow{2}{*}{$\mathrm{P}_{2}$} & \multirow{2}{*}{$\mathrm{P}_{3}$} & \multirow{2}{*}{ CV\% } \\
\hline & & VG3 & VG1126 & & & & & \\
\hline \multirow{6}{*}{ SF } & Control & $29.920 b C$ & $33.429 \mathrm{aA}$ & $31.675 \mathrm{~B}$ & \multirow{6}{*}{$<0.001$} & \multirow{6}{*}{$<0.001$} & \multirow{6}{*}{$\begin{array}{l}<0.00 \\
1\end{array}$} & \multirow{6}{*}{4.070} \\
\hline & LP & $22.294 \mathrm{aE}$ & $20.935 \mathrm{aC}$ & $21.615 \mathrm{E}$ & & & & \\
\hline & Urea & $27.922 \mathrm{aD}$ & $25.469 \mathrm{bB}$ & $26.696 \mathrm{D}$ & & & & \\
\hline & $\mathrm{NaOH}$ & $34.152 \mathrm{aB}$ & $26.737 \mathrm{bB}$ & $30.445 \mathrm{C}$ & & & & \\
\hline & $\mathrm{CaO}$ & $44.371 \mathrm{aA}$ & $26.790 \mathrm{bB}$ & $35.550 \mathrm{~A}$ & & & & \\
\hline & Mean & $31.732 \mathrm{a}$ & $26.672 b$ & & & & & \\
\hline \multirow{6}{*}{$48 \mathrm{~h}$} & Control & $51.612 \mathrm{aC}$ & $40.255 \mathrm{bD}$ & $45.933 \mathrm{C}$ & \multirow{6}{*}{$<0.001$} & \multirow{6}{*}{$<0.001$} & \multirow{6}{*}{$\begin{array}{l}<0.00 \\
1\end{array}$} & \multirow{6}{*}{4.490} \\
\hline & LP & $45.189 \mathrm{aD}$ & $45.093 \mathrm{aC}$ & $45.141 \mathrm{C}$ & & & & \\
\hline & Urea & $52.582 \mathrm{aC}$ & $48.305 \mathrm{bB}$ & $50.443 B$ & & & & \\
\hline & $\mathrm{NaOH}$ & $58.483 \mathrm{aB}$ & $52.922 \mathrm{bA}$ & $55.703 \mathrm{~A}$ & & & & \\
\hline & $\mathrm{CaO}$ & $62.610 \mathrm{aA}$ & $49.473 \mathrm{bB}$ & $56.041 \mathrm{~A}$ & & & & \\
\hline & Mean & $54.095 \mathrm{a}$ & $47.209 b$ & & & & & \\
\hline \multirow{5}{*}{$72 \mathrm{~h}$} & Control & $54.608 \mathrm{aD}$ & $48.341 \mathrm{bC}$ & $51.474 \mathrm{C}$ & \multirow{5}{*}{$<0.001$} & \multirow{5}{*}{$<0.001$} & \multirow{5}{*}{$\begin{array}{l}<0.00 \\
1\end{array}$} & \multirow{5}{*}{3.110} \\
\hline & LP & $50.051 \mathrm{aE}$ & $48.910 \mathrm{aC}$ & 49.480D & & & & \\
\hline & Urea & $56.865 \mathrm{aC}$ & $53.288 \mathrm{bB}$ & $55.077 \mathrm{~B}$ & & & & \\
\hline & $\mathrm{NaOH}$ & $61.451 \mathrm{aB}$ & $56.078 \mathrm{bA}$ & $58.765 \mathrm{~A}$ & & & & \\
\hline & $\mathrm{CaO}$ & $67.439 \mathrm{aA}$ & $52.014 \mathrm{bB}$ & $59.727 \mathrm{~A}$ & & & & \\
\hline
\end{tabular}




$$
\text { Mean 58.083a } 51.726 \mathrm{~b}
$$

Means followed by common lowercase letters in the row and uppercase letters in the column do not differ from each other according to the Scott Knott test at the 5\% probability level.

SF: soluble fraction.

Inocula: Control - no inoculum; LP - Lactobacillus plantarum; Urea - urea; $\mathrm{NaOH}$ - sodium hydroxide; $\mathrm{CaO}$ - calcium oxide. $\mathrm{P}_{1}$ - difference between cultivars; $\mathrm{P}_{2}$ - difference between additives; $\mathrm{P}_{3}$ - cultivar $\times$ additive interaction.

By analyzing the in vitro degradation of NDF in the silages from the two energycane cultivars, it is observed that the soluble fraction of cultivar VG1126 was similar to that of cultivar VG3 when the former was inoculated with LP or urea (Table 5). Additionally, the soluble fraction of cultivar VG3 was higher when it was inoculated with urea, $\mathrm{NaOH}$ or $\mathrm{CaO}$, whereas for cultivar VG1126, the use or non-use of any of the additives did not result in an increase in the soluble fraction.

The in vitro NDF degradability of both energy-cane cultivars at $48 \mathrm{~h}$ was similar when cultivar VG1126 was inoculated with $\mathrm{LP}$ or $\mathrm{NaOH}$ (Table 5). The soluble fraction and degradability at $48 \mathrm{~h}$ in cultivar VG3 was higher when the silage was inoculated with urea, $\mathrm{NaOH}$ or $\mathrm{CaO}$. Non-inoculation of cultivar VG1126 compromised in vitro degradation up to $48 \mathrm{~h}$.

At $72 \mathrm{~h}$ of fermentation, in vitro NDF degradability in cultivar VG3 was lowest when no inocula were used or when the silage was inoculated with LP (Table 5). Cultivar VG1126 had its degradation reduced when inoculated with LP or $\mathrm{CaO}$.

Table 5. Mean in vitro neutral detergent fiber degradability values (\%) in silages from two energy-cane cultivars treated with different additives, at 48 and $72 \mathrm{~h}$.

\begin{tabular}{|c|c|c|c|c|c|c|c|c|}
\hline $\begin{array}{l}\text { Variabl } \\
\mathrm{e}\end{array}$ & $\begin{array}{l}\text { Additiv } \\
\mathrm{e}\end{array}$ & Cultivar & VG1126 & Mean & $\mathrm{P}_{1}$ & $\mathrm{P}_{2}$ & $\mathrm{P}_{3}$ & $\begin{array}{l}\mathrm{CV} \\
\%\end{array}$ \\
\hline \multirow{8}{*}{ SF } & Control & $1.351 \mathrm{aB}$ & $1.162 \mathrm{bA}$ & 0.094B & \multirow{6}{*}{$\begin{array}{l}<0.00 \\
1\end{array}$} & \multirow{6}{*}{0.006} & \multirow{6}{*}{0.011} & \multirow{6}{*}{$\begin{array}{l}160 . \\
0\end{array}$} \\
\hline & LP & $0.623 \mathrm{aB}$ & $0.829 \mathrm{aA}$ & $0.103 \mathrm{~B}$ & & & & \\
\hline & Urea & $2.452 \mathrm{aA}$ & $0.535 \mathrm{aA}$ & $1.494 \mathrm{~A}$ & & & & \\
\hline & $\mathrm{NaOH}$ & $2.523 \mathrm{aA}$ & $0.243 \mathrm{bA}$ & $1.383 \mathrm{~A}$ & & & & \\
\hline & $\mathrm{CaO}$ & $4.522 \mathrm{aA}$ & $0.599 \mathrm{bA}$ & $2.560 \mathrm{~A}$ & & & & \\
\hline & Mean & $2.045 \mathrm{a}$ & $0.209 b$ & & & & & \\
\hline & Control & $33.439 a$ & $22.169 b$ & 27.804 & \multirow{6}{*}{$\begin{array}{l}<0.00 \\
1\end{array}$} & \multirow{6}{*}{$\begin{array}{l}<0.00 \\
1\end{array}$} & \multirow{6}{*}{$\begin{array}{l}<0.00 \\
1\end{array}$} & \multirow{6}{*}{8.87} \\
\hline & Contror & B & $\mathrm{C}$ & $\mathrm{D}$ & & & & \\
\hline \multirow{4}{*}{$48 \mathrm{~h}$} & LP & $\begin{array}{l}31.544 a \\
B\end{array}$ & $\begin{array}{l}30.211 \mathrm{a} \\
\mathrm{B}\end{array}$ & $\begin{array}{l}30.878 \\
\mathrm{C}\end{array}$ & & & & \\
\hline & Uree & $35.158 \mathrm{a}$ & $30.340 b$ & 32.749 & & & & \\
\hline & urea & A & B & B & & & & \\
\hline & $\mathrm{NaOH}$ & $\begin{array}{l}37.418 a \\
A\end{array}$ & $35.133 \mathrm{a}$ & 36.276 & & & & \\
\hline
\end{tabular}




\begin{tabular}{|c|c|c|c|c|c|c|c|c|}
\hline & $\mathrm{CaO}$ & $\begin{array}{l}37.310 \mathrm{a} \\
\mathrm{A}\end{array}$ & $\begin{array}{l}31.255 b \\
\mathrm{~B}\end{array}$ & $\begin{array}{l}34.282 \\
\text { B } \\
\end{array}$ & & & & \\
\hline & Mean & $34.974 a$ & $29.821 b$ & & & & & \\
\hline \multirow{11}{*}{$72 \mathrm{~h}$} & Control & $39.310 a$ & $38.091 \mathrm{a}$ & 38.700 & \multirow{11}{*}{$\begin{array}{l}<0.00 \\
1\end{array}$} & \multirow{11}{*}{0.038} & \multirow{11}{*}{0.018} & \multirow{11}{*}{$\begin{array}{l}10.8 \\
1\end{array}$} \\
\hline & Contror & B & A & A & & & & \\
\hline & I P & $36.297 \mathrm{a}$ & $34.417 \mathrm{a}$ & 35.357 & & & & \\
\hline & LP & B & B & B & & & & \\
\hline & Urea & $42.945 a$ & $37.582 b$ & 40.263 & & & & \\
\hline & & A & A & A & & & & \\
\hline & \multirow{2}{*}{$\mathrm{NaOH}$} & $42.031 \mathrm{a}$ & $38.457 \mathrm{a}$ & 40.244 & & & & \\
\hline & & A & A & A & & & & \\
\hline & \multirow{2}{*}{$\mathrm{CaO}$} & $44.996 \mathrm{a}$ & $32.875 b$ & 38.936 & & & & \\
\hline & & A & $\mathrm{B}$ & A & & & & \\
\hline & Mean & $41.116 a$ & $36.284 b$ & & & & & \\
\hline
\end{tabular}

Means followed by common lowercase letters in the row and uppercase letters in the column do not differ from each other according to the Scott Knott test at the 5\% probability level.

SF: soluble fraction.

Inocula: Control - no inoculum; LP Lactobacillus plantarum; Urea - urea; $\mathrm{NaOH}$ - sodium hydroxide; $\mathrm{CaO}$ -

calcium oxide. $\mathrm{P}_{1}$ - difference between cultivars; $\mathrm{P}_{2}$ - difference between additives; $\mathrm{P}_{3}-$ cultivar $\times$ additive interaction.

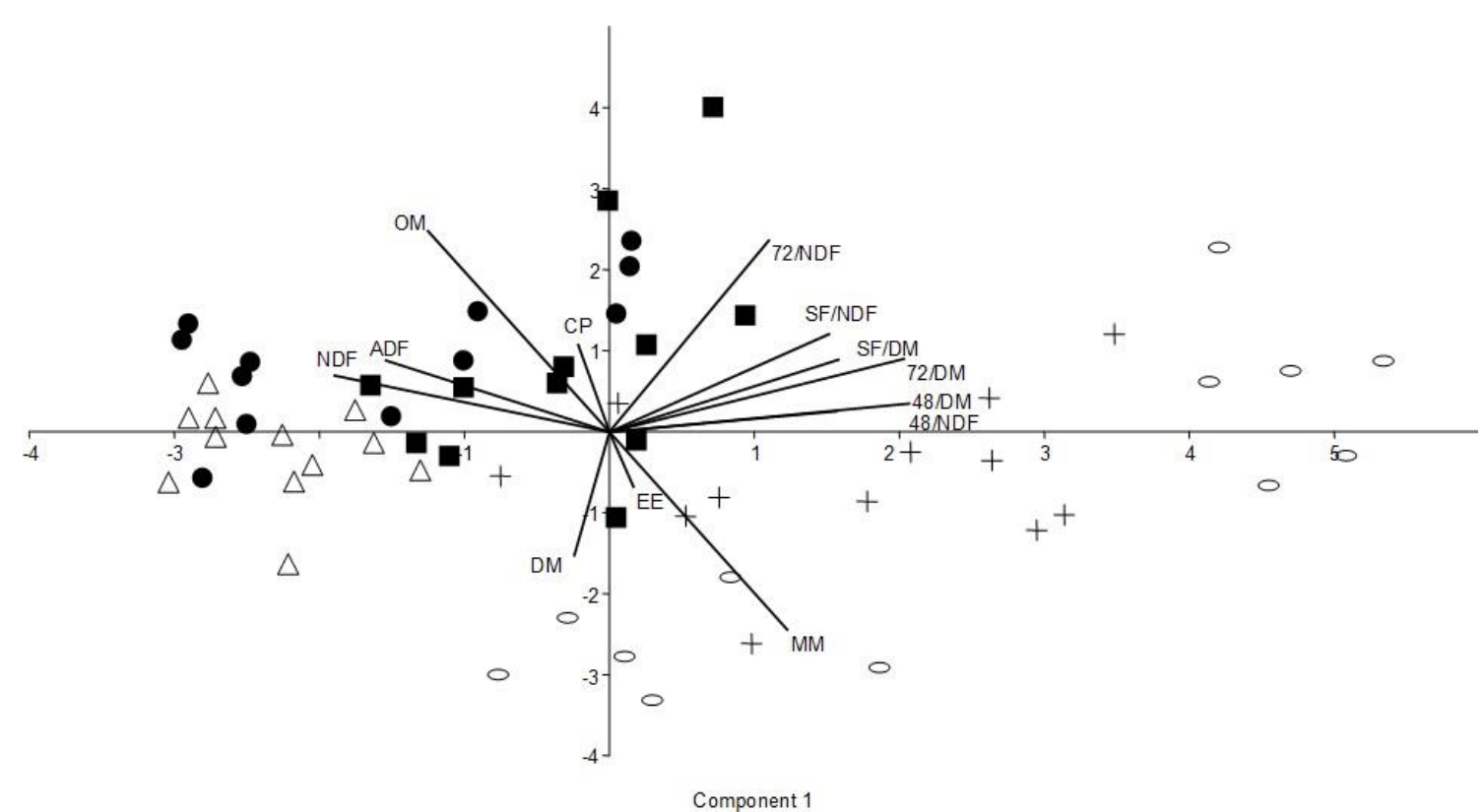

Figure 1. Principal component analysis of quality of silage from two energy-cane cultivars produced with different additives (Treatments: Triangle - LP: Lactobacillus plantarum; Empty circle - $\mathrm{CaO}$ : calcium oxide; Filled circle - Control, without inoculum; Square - urea; Cross - $\mathrm{NaOH}$ : sodium hydroxide).

Cultivars VG3 and VG1126 formed overlapping groups, which did not differ from each other. The main correlations in the analysis were the NDF, $\mathrm{ADF}$ and OM vectors, which were proportional to each other, that is, when one increases 
the other also increases. These same vectors were inversely proportional to $\mathrm{MM}$, meaning when NDF, ADF and OM increase, MM decreases. Crude protein was also listed in this set of variables, but with little effect on the differences in cultivars (VG3 and VG1126).

Cultivar VG3 correlated with the SF/NDF, SF/DM, 72h/DM and 48h/DM variables, all of which were related to each other. These variables were inversely proportional to NDF, ADF and $\mathrm{OM}$. The groups formed by the $\mathrm{NaOH}$ and $\mathrm{CaO}$ additives showed a higher correlation with each other, being related to the MM, SF/NDF and SF/DM parameters. The Lactobacillus plantarum and urea additives and control exhibited greater correlation with each other and were related to the OM, NDF, ADF parameters and weakly to $\mathrm{CP}$.

\section{DISCUSSION}

Knowing the lignocellulosic composition of a feedstuff is essential for formulating ruminant diets (Table 1). When working with silage, another important factor to be considered is the quality of the material before the ensiling process (Table 2), so at the end of the process new analyses can be carried out and the success or non-success of the conservation process attested.

The results show that there was a reduction in DM content when the energy-cane cultivars were ensiled (Table 2 and Table 3). This reduction may occur during the fermentation of the material. According to Alli et al. (1983) and Evangelista et al. (2009), this decrease in DM levels is in response to the consumption of soluble carbohydrates by microorganisms. As stated by McDonald et al. (1991), this reduction is worrying, as it may be associated with yeast fermentation, which, in addition to significantly reducing nutritional value, can reduce voluntary consumption of silage by the animal.

The decreased DM losses following the use of $\mathrm{CaO}$ in the silage from cultivar VG3 was an expected result (Table 3). Studies led by Vilela et al. (2014) showed that the use of $\mathrm{CaO}$ in the ensiling of sugarcane reduces variations in the silage DM levels.

The CP and EE contents of the silages were similar to those of fresh energy cane (Table 3). As also found in silages from conventional cultivars, the $\mathrm{CP}$ levels in both cultivars of energy cane are low. This, however, does not limit its use, since its complementary addition in the diet can be easily done at the trough. The increased CP levels observed in the silage treated with of urea as an inoculum are considerable and were already expected. Lopes \& Evangelista (2010) reported increases of up to $12.33 \%$ in CP contents when $1 \%$ of the sugarcane fresh mass was inoculated with urea.

Another important result was the reduction in NDF contents of the silages from the two energy-cane cultivars when they were inoculated with $\mathrm{NaOH}$ or $\mathrm{CaO}$ (Table 3). This reduction suggests the occurrence of alkaline hydrolysis with partial solubilization of hemicellulose (Reis et al., 1991). Similar results were described by Pedroso et al. (2007), who used $1 \% \mathrm{NaOH}$ and observed a decrease of approximately $14 \%$ in the NDF contents of the silage.

In nutritional terms, these results are of great interest, since a reduction of fibrous components improves the digestibility of forage (Cruz et al., 2011). According to NRC (2001), NDF has low rates of degradation, and the decreases 
observed here may provide a higher DM intake by the animals. Reductions in ADF levels were also observed when the silage was inoculated with $\mathrm{NaOH}$ or $\mathrm{CaO}$, which was already expected. Carvalho et al. (2012) reported that the addition of alkaline additives such as $\mathrm{NaOH}$ and $\mathrm{CaO}$ induces reductions in fibrous components in sugarcane silage. The in vitro degradability values of the silages from the two energy-cane cultivars evaluated here are invaluable for further studies (Table 4). Sodium hydroxide significantly increased the DM degradation of cultivar VG1126 at $48 \mathrm{~h}$ and $72 \mathrm{~h}$ of fermentation. This increased degradation rate drives the use of $\mathrm{NaOH}$ for the preservation of silage from this cultivar. Several studies have shown the advantage of using $\mathrm{NaOH}$, e.g., Ezequiel et al. (2005) reported a $45 \%$ increase in digestibility and a $25 \%$ increase in DM intake of sugarcane treated with $1.5 \% \mathrm{NaOH}$, compared with fresh sugarcane.

For cultivar VG3, $\mathrm{CaO}$ was more advantageous in the degradation of silage DM at $48 \mathrm{~h}$ and $72 \mathrm{~h}$ of fermentation. With the restrictions on the use of $\mathrm{NaOH}$ due to the risks inherent to its handling, to the environment, and the risk of reducing the useful life of machinery, $\mathrm{CaO}$ (quicklime) emerges as an excellent inoculum. Balieiro-Neto et al. (2007) also demonstrated the benefits of using $\mathrm{CaO}$. In addition to reporting increased digestibility in sugarcane before silage, those authors also report increased digestibility and recovery of digestible DM and non-fibrous carbohydrates after opening the silos.

In general, the effect of alkaline products such as $\mathrm{NaOH}$ and $\mathrm{CaO}$ on low-quality roughage (such as energy cane) is due to the partial solubilization of hemicellulose and the expansion of cellulose as a result of the hydrolytic attack of these substances on ester-type covalent bonds the between lignin and the cell wall. This allows the access of ruminal microbial enzymes to the cell wall, increasing the soluble fraction, reducing the insoluble fraction and elevating digestibility (Van Soest, 1994). Therefore, the results obtained in the present experiment corroborate these statements.

\section{CONCLUSIONS}

Here we show that the additives influence the chemical composition of the evaluated sugarcane silages. The alkaline additives $\mathrm{NaOH}$ and $\mathrm{CaO}$ can be used to reduce the fiber content and increase the mineral matter content of silages from energy-cane cultivars VG3 and VG1126. Additionally, the use of $\mathrm{NaOH}$ and $\mathrm{CaO}$ favors the degradability of the ensiled material, increasing the availability of the soluble fraction and fiber degradation. The use of Lactobacillus plantarum can be dismissed, since this additive does not favor degradability in silages from energy-cane cultivars VG3 and VG1126.

\section{Acknowledgement}

This research did not receive any specific funding. We would like to thank the Graduate Program in Animal Science at the Universidade Federal de Goias for their support and encouragement to research.

\section{REFERENCES}

ALLI, I.; FAIRBAIRN. R.; BAKER, B.E. The effects of ammonia on the fermentation of chopped sugarcane. Animal Feed Science and Technology, 
v.9, p.291-299,

doi:doi.org/10.1016/0377-

8401(83)90022-6

ANKOM Technology Method 3: In vitro true digestibility using the DAISYII Incubator. Available at http://www.ankom.com/media/documen ts/. Verified 16 January 2019.

ANTONINI, S.R.C.; BASSI, A.P.G.; PARALIPPI, A.L.; SANTOS, E.G.D.; MATSUOKA, S. Deterioration and fermentability of energy cane juice. Ciência Rural, v.47, p.1-7, 2017. doi:10.1590/0103-8478cr20160860

BALIEIRO NETO, G.; SIQUEIRA, G.R.; REIS, R.A.; NOGUEIRA, J.R.; ROTH, M.T.P. Óxido de cálcio como aditivo na ensilagem de cana-de-açúcar. Revista Brasileira de Zootecnia, v.36, p. 1231-1239, 2007. doi:10.1590/S151635982007000600003

CARVALHO, B.F.; ÁVILA, C.L.S.; PINTO, J.C.; PEREIRA, W.N.; SCHWAN, R.F. Effects of propionic acid and Lactobacillus buchneri (UFLA SIL 72) addition on fermentative and microbiological characteristics of sugar cane silage treated with and without calcium oxide. Grass and Forage Science, v.67, p.462-471, 2012. doi:10.1111/j.1365-2494.2012.00863.x

CRUZ, B.C.C.; CRUZ, C.L.S.; PIRES, A.J.V.; ROCHA, J.B.; SANTOS, S.; BASTOS, M.P.V. Desempenho, consumo e digestibilidade de cordeiros em confinamento recebendo silagens de capim elefante com diferentes proporções de casca desidratada de maracujá. Semina: Ciências Agrárias, v.32, p.1595-1604, 2011. doi: 10.5433/1679-0359.2011v32n4p1595
DETMANN, E.; SOUZA, M.A.; VALADARES FILHO. S.C. Métodos para análise de alimentos. Instituto Nacional de Ciência e Tecnologia de Ciência Animal, Visconde do Rio Branco, MG, Suprema, 214p, 2012.

DIAS, A.M.; ÍTAVO, L.C.V.; ÍTAVO, C.C.B.F.; BLAN, L.R.; GOMES, E.N.O.; SOARES, C.M.; LEAL, E.S.; NOGUEIRA, E.; COELHO, E.M. Ureia e glicerina bruta como aditivos na ensilagem de cana-de-açúcar. Arquivo Brasileiro de Medicina Veterinária e Zootecnia, v.66, p.1874-1882, 2014. doi:10.1590/1678-7349

EVANGELISTA, A.R.; SIQUEIRA, G.R.; LIMA， J.A.; LOPES， J.; REZENDE, A.V. Alterações bromatológicas e fermentativas durante o armazenamento de silagens de canade-açúcar com e sem milho desintegrado com palha e sabugo. Revista Brasileira de Zootecnia, v.38, p.20-26, 2009. doi:10.1590/S151635982009000100003

GUIMARÃES, G.; LANA, R.P.; REI, R.S.; VELOSO, C.M.; SOUZA, M.R.M.; RODRIGUES, R.C.; CAMPOS, S.A. Produção de cana-deaçúcar adubada com cama de frango. Brasileira de Saúde e Produção Animal, v.17, p.617-625, 2016. doi:10.1590/s151999402016000400006

LOPES, J.; EVANGELISTA, A.R. Características bromatológicas, fermentativas e população de leveduras de silagem de cana-de-açúcar acrescidas de ureia e aditivos absorventes de umidade. Revista Brasileira de Zootecnia, v.39, p.984-991, 2010. 
doi:10.1590/S1516-

35982010000500007

MATSUOKA, S.; KENNEDY, A.J.; SANTOS, E.G.; TOMAZELA, A.L., RUBIO, L.C. Energy Cane: Its Concept, Development, Characteristics, and Prospects. Advances in Botany, v.2014, p.1-13, 2014. doi:10.1155/2014/597275

MCDONALD, P.; HENDERSON, A.R.; HERON, S.J.E. 1991. The biochemistry of silage (2nd edn) Marlow: Chalcomb Publications. 340p.

MORAES， R.L.; RIBEIRO, K.G.; PEREIRA, O.G.; MARCONDES, M.I.; CARDOSO, L.L. Silagem de cana-deaçúcar tratada com inoculantes microbianos e suas misturas. Revista Brasileira de Agropecuária Sustentável, v.7, p.76-83, 2017. doi:10.21206/rbas.v7i3.391

NRC-National Research Council. 2001. Nutrients requirements of dairy cattle (7nd edn) rev. Washington, D.C.: National Academy of Sciences.

PEDROSO, A.F.; NUSSIO, L.G.; LOURES, D.R.S.; PAZIANI, S.F.; IGARASI, M.S.; COELHO, R.M.; HORII, J.; ANDRADE, R.A. Efeito do tratamento com aditivos químicos $\mathrm{e}$ inoculantes bacterianos nas perdas e na qualidade de silagens de cana-de-açúcar. Revista Brasileira de Zootecnia, v.36, p.558-564, 2007. doi:10.1590/S151635982007000300006

PEREIRA, A.S.; OLIVEIRA， G.C.; KLIEMANN, H.J.; BALBINO, L.C.; FRANÇA, A.F.S.; CARVALHO, E.R. Influence of different grazing systems on physical properties and aggregation in savannah soils. Pesquisa Agropecuária
Tropical, v.40, p.274-282, 2010. doi:10.5216/pat.v40i3.5608

REIS, R.A.; GARCIA, R.; QUEIROZ, A.C.; SILVA, D.J.; FERREIRA, J. Q. Efeitos da amonização sobre a qualidade dos fenos de gramíneas tropicais. Pesquisa Agropecuária Brasileira, v,26, p.1183-1191, 1991.

VAN SOEST, P.J. 1994. Nutrition al ecology of the ruminant (2nd edn) Ithaca: Cornell University. 